\title{
Notes on reproduction of the adorned graceful brown snake, Rhadinea decorata (Serpentes, Colubridae), from Costa Rica
}

\author{
Stephen R. Goldberg \\ Department of Biology, Whittier College, Whittier, California 90608, USA. E-mail: sgoldberg@whittier.edu.
}

Keywords: Serpentes, Colubridae, Rhadinea decorata, reproduction, Costa Rica.

The Adorned Graceful Brown Snake Rhadinea decorata (Colubridae) is known from humid broadleaf evergreen forests from southern Mexico to Ecuador; it is active in the daytime and eats mainly Eleutherodactylus frogs and their terrestrial eggs (Savage 2002). Solórzano (2004) reported $R$. decorata clutch sizes of up to four eggs. The purpose of this paper is to present new information on the reproductive cycle of $R$. decorata from Costa Rica based on a histological examination of gonadal material from museum specimens. The first information on the timing of the testicular cycle is also presented. Comparisons are made with the timing of testicular cycles of other snakes from Costa Rica as part of an ongoing series of studies on the reproductive biology of snakes from this area.

A sample of 22 specimens of $R$. decorata from Costa Rica (collected 1959-1985) was examined from the herpetology collection of the Natural History Museum of Los Angeles County (LACM) Los Angeles, California, USA (Appendix I). Counts were made of enlarged ovarian follicles ( $>8 \mathrm{~mm}$ length) or oviductal

Received 24 April 2007.

Accepted 8 August 2007.

Distributed December 2007. eggs. The left testis and vas deferens were removed from males and the left ovary was removed from females for histological examination. Tissues were embedded in paraffin, sectioned at $5 \mu \mathrm{m}$ and stained with hematoxylin followed by eosin counterstain. Testis slides were examined to determine the stage of the testicular cycle and ovary slides were examined for the presence of yolk deposition (secondary vitellogenesis sensu Aldridge 1979). Follicles in advanced stages of yolk deposition or oviductal eggs were not examined histologically. An unpaired $t$ test was used to compare male and female mean body sizes (SVL) (Instat vers. 3.0b, Graphpad Software, San Diego, CA).

Seven females (mean snout-vent length [SVL] = $229 \mathrm{~mm} \pm 23 \mathrm{SD}$, range: $208-250 \mathrm{~mm}$ ); 13 males (SVL $=190 \mathrm{~mm} \pm 29 \mathrm{SD}$, range: 172 $207 \mathrm{~mm}$ ) and 2 neonates SVL 90 and $98 \mathrm{~mm}$ were examined.

All testes examined exhibited spermiogenesis with metamorphosing spermatids and sperm present. Vasa deferentia also contained sperm. The following monthly numbers of $R$. decorata males were undergoing spermiogenesis: February (1), March (3), May (2), July (2), August (2), September (2), October (1). The smallest spermiogenic male measured $120 \mathrm{~mm}$ SVL (LACM 131127). 
Females were larger than males (unpaired $t$ test, $18 d f, t=3.07, P=0.007)$. Three females with oviductal eggs were observed, one (1 egg) collected in January (LACM 154320), one (2 eggs) collected 19 July-2 August (LACM 154313) and one (3 eggs) collected in August (LACM 154317). The smallest reproductively active $R$. decorata female (1 oviductal egg) measured 203 mm SVL (LACM 154320). Three females were undergoing yolk deposition = secondary vitellogenesis; one each from July, August and December. One female (SVL $=202$ $\mathrm{mm}$ ) from February was reproductively inactive (no yolk deposition). Most of the females (86.7\%) were reproductively active. There was no evidence that $R$. decorata from Costa Rica produce more than one clutch of eggs per year (oviductal eggs and yolk deposition in the same female) although the existence of reproductively active females in different parts of the year: January, July, August, December suggests that this might be possible. Solórzano (2004) previously reported clutches of up to four eggs for $R$. decorata but did not give a mean clutch size.Two (presumably) neonates of $R$. decorata were collected, one each in September and November.

Results obtained in the present study suggest that $R$. decorata males produce sperm throughout the year. Extended testicular cycles have also been reported in other snakes from Costa Rica: Drymobius margaritiferus (Goldberg 2003a), Dendrophidion sp. (Goldberg 2003b), Ninia maculata (Goldberg 2004a), Erythrolamprus bizona and E. mimus (Goldberg 2004b), Micrurus nigrocinctus (Goldberg 2004c), Hydromorphus concolor (Goldberg 2006a), Mastigodryas melanolomus (Goldberg 2006b), and Geophis godmani (Goldberg 2007). Whether this is typical of snakes from Costa Rica must await histological examination of testes from additional species of Costa Rican snakes.

The preceding observations on the reproductive cycle of males and females indicates that $R$. decorata has a prolonged reproductive cycle in Costa Rica in which both sexes are in reproductive condition, at least, through most of the year. This fits into the "polyestrous with continuous reproduction" of Saint Girons (1982). Fitch (1982) reported yearround breeding in snakes from some aseasonal equatorial regions. Zug et al. (1979) reported continuous or aseasonal reproduction for the colubrid snakes, Dipsas catesbyi in Peru and Imantodes cenchoa from Peru/Ecuador. In contrast the congener Rhadinea flavilata which occurs in the southeastern United States follows a seasonal reproductive cycle in which breeding occurs in the spring and eggs are laid from late May to mid-August (Ernst and Ernst 2004). The timing of this reproductive cycle is similar to those of other colubrid snakes from north temperate areas of North America (e.g., Goldberg and Parker 1975) and fits into the “aestival spermatogenesis” of Saint Girons (1982). Subsequent investigations are needed to ascertain how widespread extended reproductive cycles are in the snakes of Costa Rica.

\section{Acknowledgements}

I thank Christine Thacker (LACM) for permission to examine specimens. Jessica Carlson assisted with histology. Snakes are part of the CRE collection donated to LACM by Jay Savage in 1998 .

\section{References}

Aldridge, R. D. 1979. Female reproductive cycles of the snakes Arizona elegans and Crotalus viridis. Herpetologica 35: 256-261.

Ernst, C. H. and C. H. Ernst. 2003. Snakes of the United States and Canada. Washington. Smithsonian Books. 668 pp.

Fitch, H. S. 1982. Reproductive cycles in tropical reptiles. Occasional Papers of the Museum of Natural History of the University of Kansas 96: 1-53.

Goldberg, S. R. 2003a. Reproduction in the speckled racer, Drymobius margaritiferus (Serpentes: Colubridae), from Mexico and Central America. Texas Journal of Science 55: 195-200. 
Goldberg, S. R. 2003b. Reproduction in four species of Dendrophidion from Costa Rica (Serpentes: Colubridae). Transactions of the Illinois State Academy of Science 96: 295-300.

Goldberg, S. R. 2004a. Reproduction in the coffee snake, Ninia maculata (Serpentes: Colubridae), from Costa Rica. Texas Journal of Science 56: 81-84.

Goldberg, S. R. 2004b. Notes on reproduction in the false coral snakes, Erythrolamprus bizona and Erythrolamprus mimus (Serpentes: Colubridae) from Costa Rica. Texas Journal of Science 56: 171-174.

Goldberg, S. R. 2004c. Notes on reproduction in the Central American coral snake, Micrurus nigrocinctus (Serpentes: Elapidae) from Costa Rica. Caribbean Journal of Science 40: 420-422.

Goldberg, S. R. 2006a. Note on the testicular cycle of the Costa Rica water snake, Hydromorphus concolor (Serpentes: Colubridae). Bulletin of the Maryland Herpetological Society 42: 169-170.

Goldberg, S. R. 2006b. Reproductive cycle of the salmonbellied racer, Mastigodryas melanolomus (Serpentes, Colubridae), from Costa Rica. Phyllomedusa 5: 145148.
Goldberg, S. R. 2007. Note on the testicular cycle of Godman's earth snake, Geophis godmani (Serpentes: Colubridae) from Costa Rica. Bulletin of the Chicago Herpetological Society 42: 7-8.

Goldberg, S. R. and W. S. Parker. 1975. Seasonal testicular histology of the colubrid snakes, Masticophis taeniatus and Pituophis melanoleucus. Herpetologica 31: $317-322$.

Saint Girons, H. 1982. Reproductive cycles of male snakes and their relationships with climate and female reproductive cycles. Herpetologica 38: 5-16.

Savage, J. M. 2002. The Amphibians and Reptiles of Costa Rica: A Herpetofauna Between Two Continents, Between Two Seas. Chicago. The University of Chicago Press. 934 pp.

Solórzano, A. 2004. Snakes of Costa Rica: Distribution, Taxonomy, and Natural History. Instituto Nacional de Biodiversidad, Costa Rica. 791 pp.

Zug, G. R., S. B. Hedges and S. Sunkel. 1979. Variation in reproductive parameters of three neotropical snakes, Coniophanes fissidens, Dipsas catesbyi, and Imantodes cenchoa. Smithsonian Contributions in Zoology 300: 1-20.

\section{Appendix I - Specimens Examined}

COSTA RICA - Alajuela, 131127; Cartago 154316; Heredia 154306, 154307, 154313, 154315, 154317, 154320, 154322, 154324,
154326, 154329, 154334; Limón 154311, 154312, 154323, 154333; Puntarenas 154308, 154310, 154314, 154319, 154321. 